\title{
O językach mniejszościowych (ze szczególnym uwzględnieniem walijskiego)
}

On minority languages (with particular consideration of Welsh)

\author{
Marcin LĄCZEK \\ Uniwersytet Warszawski/ University of Warsaw \\ E-mail: m.laczek@uw.edu.pl,
}

\begin{abstract}
The article concentrates on minority languages. At its beginning, the author focuses on the most crucial legislation initiatives that have been adopted by the Council of Europe; a prompt reference is then made to the concepts of bilingualism, multilingualism, plurilingualism as well as ethnic variety. In the further course of his analyses, and after providing the data gathered by adequate institutions of the European Union and UNESCO, he refers to the Welsh language as an example of a minority language.
\end{abstract}

Keywords: minority languages, bilingualism, multilingualism, plurilingualism, ethnic diversity, the Welsh language

\section{Wstęp}

Autor niniejszego tekstu, po przywołaniu podstawowych aktów prawnych traktujących o językach mniejszościowych oraz założeń edukacji dwujęzycznej, nakreśli aktualny stan badań języków mniejszościowych. Istnieje kilka powodów, dla których Autor zajął się tą tematyką. Te najważniejsze, powtarzając za J. Cenoz i D. Gorter (2008), to większe zainteresowanie językami mniejszościowymi na świecie, wkład użytkowników posługujących się językami mniejszościowymi w wielojęzyczność per se czy wpływ języków mniejszościowych na główne obszary badawcze lingwistyki stosowanej ${ }^{1}$.

Powyższe zaprezentowane zostanie ze szczególnym uwzględnieniem języka walijskiego, a przesłanki ku temu były dwojakie: pierwszą stanowił czynnik o podłożu stricte historycznym. Otóż język ten, jak podaje J. Davies (1993: 12) - spośród wszystkich języków, którymi obecnie posługują się Brytyjczycy - ma najstarsze, sięgające 2500 tysiąca lat wstecz, korzenie (a, być może, i 4000 lat) w porównaniu do piętnastu stuleci istnienia angielskiego czy gaelickiego szkockiego ([Scottish/Scots] Gaelic). Drugim powodem była niekwestionowana pozycja Walii w zakresie edukacji dwujęzycznej, a zwłaszcza powołanie do życia na Uniwersytecie w Bangor w 2006

\footnotetext{
${ }^{1}$ Szeroko o lingwistyce stosowanej pisał F. Grucza (zob. m. in. F. Grucza 2017a).
} 
roku pierwszego w skali Zjednoczonego Królestwa Wielkiej Brytanii i Irlandii Północnej centrum badawczego o nazwie ESRC Centre for Research on Bilingualism in Theory and Practice.

\section{Uwarunkowania prawne}

Od początku lat siedemdziesiątych - w odniesieniu do języków mniejszościowych (a w kontekście prac nad migracją w Europie Zachodniej), Rada Europy podjęła szereg inicjatyw, których celem była ochrona i promowanie historycznych języków regionalnych i mniejszościowych w Europie ${ }^{2}$. Spośród najważniejszych przywołać, choćby z nazwy, należy: The Framework Convention for the Protection of National Minorities, The European Charter for Regional or Minority Languages, Recommendation No. R (98) 6 of the Committee of Ministers, The Treaty of Lisbon. ${ }^{3} \mathrm{~W}$ ostatniej dekadzie uległy one zresztą $\mathrm{w}$ większym stopniu rozszerzeniu o mniejszości narodowe, choć pamiętać trzeba, że już w 1983 r. Unia Europejska przyjęła plan działania na rzecz promowania i ochrony mniejszościowych i regionalnych języków i kultury: The Action Line for the Promotion and Safeguard of Minority and Regional Languages and Cultures ${ }^{4}$.

Innymi równie istotnymi dokumentami w sprawie europejskiej strategii na rzecz wielojęzyczności są: opublikowana po raz pierwszy w 2005 roku (a zaktualizowana w roku 2011) A New Framework Strategy for Multilingualism czy Rezolucja Rady Unii Europejskiej - Council Resolution of 21 November 2008 on a European strategy for multilingualism, która stanowi m.in., że różnorodność językowa ${ }^{5} \mathrm{i}$ kulturowa jest nieodłączoną częścią europejskiej tożsamości, a promowanie rzadziej używanych języków europejskich w istotny sposób służy wielojęzyczności:

- linguistic and cultural diversity is part and parcel of the European identity; it is at once a shared heritage, a wealth, a challenge and an asset for Europe;

- the promotion of less widely used European languages represents an important contribution to multilingualism;

- significant efforts should still be made to promote language learning and to value the cultural aspects of linguistic diversity at all levels of education and training, while also improving information on the variety of European languages and their dissemination across the world (Council Resolution of $21 \mathrm{No}-$ vember 2008 on a European strategy for multilingualism 2008: 1-2).

\footnotetext{
${ }^{2}$ Ciekawe i przydatne informacje dostępne są na stronie European Union Agency for Fundamental Rights: http://fra.europa.eu/en/tags/minorities.

${ }^{3}$ Autor, w miejscu gdzie uznał to za stosowne, podaje wyłącznie/ także angielskie nazewnictwo.

${ }^{4}$ W 2003 roku Komisja Europejska przyjęła The Action Plan Promoting Language Learning and Linguistic Diversity. Na gruncie polskim przedmiotowe kwestie reguluje Ustawa z dnia 6 stycznia 2005 r. o mniejszościach narodowych $i$ etnicznych oraz o języku regionalnym (Dz. U. Nr 17, poz. 141, z późn. zm.). Zob. także: M. Budyta-Budzyńska (2010).

${ }^{5} \mathrm{O}$ korzyściach płynących z zachowania językowej różnorodności pisze np. D. Crystal (2000).
} 
Ciekawe dane prezentuje również raport A.F. Atger (2009) pod tytułem Education and political participation of migrants and ethnic minorities in the EU $U^{6}$, celem którego jest przedstawienie ogólnego zarysu dotyczącego ewoluowania idei połączenia udziału migrantów i mniejszości etnicznych w edukacji i polityce, przy wsparciu polityki Unii Europejskiej - pierwszym prawnie wiążącym instrumentem, w którym pojawiło się tego rodzaju połączenie, była dyrektywa z 1977 roku: Council Directive 77/486/EEC on the education of children of migrant workers choć jak zauważa Autorka (2009) jej implementacja, 30 lat później, nadal nie jest satysfakcjonująca ${ }^{7}$.

\section{Od dwu-/ wielojęzyczności do różnojęzyczności. Różnorodność etniczna}

Trudno jest przytoczyć, nawet w dużym skrócie, proponowane w literaturze glottodydaktycznej definicje pojęcia bilingwizmu ponieważ jest to pojęcie złożone, obejmujące szereg różnych elementów ze sfery uczącego i uczącego się. Słowa M. Olpińskiej-Szkiełko (2013: 50) stanowią dowód tej niepodważalnej redundancji:

[w] taściwie każdy z autorów zajmujących się problematyką dwujęzyczności tworzy własną terminologię lub używa określeń proponowanych przez innych badaczy, rozumiejąc je inaczej i 'wypełniając' innymi znaczeniami. Może to prowadzić do wielu nieporozumień, dlatego na wstępie rozważań o dwujęzyczności należy zwrócić uwagę na te nieścisłości. Jako synonimy funkcjonują następujące pojęcia: 'dwujęzyczność' oraz 'bilingwizm', a w odniesieniu do kilku języków - 'wielojęzyczność' lub 'multilingwizm'.

W odróżnieniu od dwujęzyczności i wielojęzyczności, dodać należy, że w wyniku prac prowadzonych przez Radę Europy, implikujących zmianę w podejściu do kształcenia językowego, funkcjonować zaczęło pojęcie różnojęzyczności. Celem użytkownika różnojęzycznego nie jest już osiągnięcie perfekcji w danym języku/ danych językach na wzór idealnego rodzimego użytkownika, a jedynie rozwinięcie językowej kompetencji w myśl założenia, że

kolejne doświadczenia językowe i kulturowe indywidualnego człowieka, począwszy od języka domu rodzinnego i szerszej społeczności aż po języki innych narodów (czy to nauczane w szkole, czy też poznawane w bezpośrednim kontakcie), nie są gromadzone w

\footnotetext{
${ }^{6}$ Równie cenne informacje zawarte zostały m.in. w: Multilingualism: an asset for Europe and a shared commitment (2008), Multilingualism: Between Policy Objectives and Implementation (2008), Policy recommendations for the Promotion of Multilingualism in the European Union (2011), Protecting and developing historical linguistic minorities under the Lisbon Treaty (2011).

${ }^{7}$ W dyrektywie Rady 77/486/EWG z dnia 25 lipca 1977 r. zostały zapisane zajęcia w języku mniejszości, tj. języku ojczystym dla pracowników migrujących w krajach Unii Europejskiej. ${ }^{8} \mathrm{~W}$ swojej pracy poświęconej rozwojowi językowemu, poznawczemu, emocjonalnemu i społecznemu dziecka, M. Olpińska-Szkiełko (2013) przedstawia najważniejsze wyniki badań naukowych na temat przyswajania mowy, dwujęzyczności i wychowania dwujęzycznego (z uwzględnieniem rysu historycznego tych badań i szczególnym wyeksponowaniem osiągnięć dokonanych w Polsce). Zob. też np. M. Łączek (2015a, 2015b, 2016a, 2016b, 2017a, 2017b, 2018).
} 
postaci odrębnych modułów, lecz składają się na jedną całościową kompetencję komunikacyjną, w której wszystkie te doświadczenia i języki wzajemnie się przenikają i na siebie wpływają. (Europejski system opisu kształcenia językowego: uczenie się, nauczanie, ocenianie 2003).

E. Lipińska i A. Seretny (2012: 28-29) podkreślają konieczność odróżnienia pojęcia bilingwizmu od: a) znajomości dwóch języków (będącego pojęciem szerszym od dwujęzyczności), a które zakłada, że ,język ojczysty nie jest opanowywany stosownie do wieku i statusu społecznego (...), a kompetencja osiągnięta w języku innym nie odbiega od umiejętności językowych rodzimych użytkowników języka, będących w tym samym wieku i mających ten sam status społeczny" oraz b) dyglosji pojmowanej jako umiejętność posługiwania się dwiema odmianami języka; wyróżnia się tu wersję niską jaką jest odmiana kontaktowa lub regionalno-kontaktowa stosowana w środowisku domowym oraz wysoką, czyli język ogólnonarodowy - przykładem pierwszej jest język polonijny, drugiej: język polski. Innym przykładem może być zestawienie języków: arabskiego i malezyjskiego (E. Bialystok 2001). Poza tym, jednostka może posiadać umiejętności dwudialektalne lub dwuskryptowe - przykładem obydwu może być język chiński (A. Lam 2006).

Grupa etniczna (gr. ethnos, czyli lud/ naród/ grupa społeczna), jak podaje Encyclopaedia Britannica (Ethnic group 2016), jest społeczną grupą lub kategorią danej populacji, która, wyróżnia się w obrębie większego (tj. liczniejszego) społeczeństwa, i która jest związana wspólną rasą, językiem, narodowością czy kulturą. Etniczność jest tożsama z językiem, kulturą i tradycjami; obywatelstwo zaś (jako koncept przeciwstawny) zakłada polityczną lojalność w stosunku do państwa terytorialnego (E. Lipińska 2013 za: U. Płatek 2007). Będąca dziedzictwem wcześniejszych podbojów terytorialnych, różnorodność etniczna stanowi jedną z form społecznej złożoności, która jest obecna w większości współczesnych społeczeństw. Przejawia się ona poprzez przymusową, indukowaną lub wolicjonalną akulturację, która określając zjawiska zachodzące na pograniczu dwu lub więcej kultur pomiędzy jednostkami i/lub grupami ${ }^{9}$ przybiera postać jednej z czterech różnych strategii zdefiniowanych przez kanadyjskiego psychologa J.W. Berry'ego (1997), tj.: asymilacji, integracji (inkluzji), marginalizacji i separacji (izolacji) w odniesieniu do społeczeństwa przyjmującego.

E.B. Ryan i H. Giles (1982) odwołują się do czterech wariantów szacowania prestiżu języka ojczystego (dominującego) i języka drugiego (mniejszościowego) oraz solidarności z grupą własną lub obcą przez przedstawicieli grupy większościowej i mniejszościowej, gdzie: a) wariant 1 zakłada powszechną preferencję dla języka dominującego (zarówno w wymiarze prestiżu języka, jak solidarności z grupą, która się tym językiem posługuje), b) wariant 2 zakłada identyfikację osób mówiących językiem mniejszości z własną grupą i utrzymanie swojego języka we wzajemnych kontaktach (język większości zachowuje wyższość pod względem prestiżu), c) wariant 3 zakłada wywalczenie równouprawnienia języka mniejszości z językiem dominującym (tylko język mniejszości cieszy się wówczas wysokim prestiżem), d) wariant 4

${ }^{9} \mathrm{Tj}$. przyswajanie i akceptację języka, systemu wartości i norm społecznych kraju osiedlenia (R. Laskowski 2009). 
zakłada solidaryzowanie się obu grup (w codziennym użyciu jest język dominujący, ale obie grupy solidaryzują się z językiem mniejszościowym jako językiem wzorcem (standardowym $)^{10}$.

Inną strategią państw na radzenie sobie z różnorodnością etniczną jest rozwój pewnej formy pluralizmu pojmowanego jako połączenie tolerancji, współzależności i separatyzmu, jak ma to miejsce w Szwajcarii czy Kanadzie (w przypadku tej pierwszej trzy największe grupy etniczne skoncentrowane są w niezależnych kantonach $\mathrm{w}$ obrębie demokratycznej federacji; w przypadku tej drugiej zaś federalny pluralizm jest mniej stabilny). ${ }^{11}$ I. Kurcz (2007) zwraca uwagę na fakt, że mamy do czynienia z inną specyfiką problemu jeśli grupa miejscowa pozostaje $\mathrm{w}$ większości, a $\mathrm{z}$ inną gdy role się odwracają i w konsekwencji to ludność napływowa jest w większości. Jako przykłady państw, gdzie panuje równoprawność obu czy więcej języków podaje: Szwajcarię (języki: francuski, niemiecki, włoski i retroromański), Belgię (języki: francuski, flamandzki i niemiecki) oraz Kanadę (języki: angielski i francuski). Autorka (2007) przywołuje także przykład Indii oraz innych nowo powstałych państw afrykańskich, mieszkańcy których posługują się językiem byłego kolonizatora jako językiem urzędowym celem nie wyróżniania (tj. przywilejowania) żadnego z istniejącej redundancji języków czy dialektami.

\section{O językach mniejszościowych (ze szczególnym uwzględnieniem walijskiego)}

Według M.P. Jones ${ }^{12}$ (2013), obecnie na świecie mówi się sześcioma/ siedmioma tysiącami języków ${ }^{13}$, z czego $97 \%$ mieszkańców posługuję się 4\% języków świata, a tylko 3\% ludności porozumiewa się za pomocą jednego z pozostałych $96 \%$ języków. Dodać trzeba, że w skali światowej wyróżnia się około 2000 języków, którymi posługuje się mniej niż 1000 użytkowników. Co więcej, rdzenne języki Europy, których liczba szacowana jest na 255, stanowią jedynie 3\% wszystkich języków na świecie;

\footnotetext{
${ }^{10}$ R. Laskowski (2009) do czynników mających wpływ na los języka mniejszościowego zalicza: status, dystans kulturowy (religia), demografię i wsparcie instytucjonalne; wśród czynników społecznych zaś wymienia: dyspersję kontra koncentrację, pochodzenie kulturowe, poziom edukacji, ocenę i samoocenę, status symboliczny, zatrudnienie (wykwalifikowany/ niewykwalifikowany/ własna działalność).

${ }^{11}$ Jedną z odmian akulturacji nakierowanej (directed acculturation, tłum. M. Ł.) jest bardziej czy mniej woluntarna asymilacja znana pod nawą amerykanizacji; w przypadku europejskich grup etnicznych (a nie mniejszości rasowych) zamieszkanie na terenie Stanów Zjednoczonych było sprawą indywidualnego lub rodzinnego wyboru, a nie podboju lub niewolnictwa (Acculturation. Anthropology 2016).

${ }^{12}$ Raport nie traktuje o językach migrantów, którymi posługują się w Europie, a które także mogą być zagrożone.

${ }^{13}$ Dokładna liczba nie jest znana ponieważ istnieją rozbieżności w kwestii zdefiniowania pojęcia ,język" (w odróżnieniu od dialektu) (M.P. Jones 2013: 14). R.G. Gordon (2005), na przykład, liczbę tę określa na 6912 (wliczając różne odmiany czy dialekty).
} 
dla porównania, mieszkańcy Azji posługują się około 2165. językami ${ }^{14}$. W Unii Europejskiej (choć jej mieszkańcy posługują się wieloma innymi językami), 24 języki zostały oficjalnie uznane za języki robocze, a 5 spośród ponad 60 rdzennych języków regionalnych i języków mniejszości (tj. kataloński, galicyjski/ galisyjski, baskijski, gaelicki szkocki oraz walijski) - za języki półoficjalne. Wszystkie pozostałe języki nie mają statusu języków oficjalnych UE.

Mówiąc o językach mających słabszą pozycję niż główne języki europejskie, M.P. Jones (2013) podaje ich następującą typologię: constitutional, regional and smaller state languages (CRSS), regional and minority languages (RML), lesser used languages, autochthonous, cross border and non-territorial languages. Mając na względzie prawną pozycję języków w mniejszym stopniu używanych na obszarze Unii Europejskiej ta klasyfikacja ulega dalszemu pogłębieniu (w zależności od stopnia przyznanego im statusu) na:

1. oficjalnie uznane za języki robocze na terenie Unii Europejskiej - są to języki, którymi posługuje się mniejszość zamieszkująca kraj sąsiadujący, jak na przykład język szwedzki w Finlandii;

2. języki, które są do pewnego stopnia uznane za języki oficjalne w krajach członkowskich lub w tej części kraju członkowskiego, w którym mieszkańcy się nimi posługują, jak na przykład język kataloński, język baskijski czy język galicyjski w Hiszpanii;

3. języki, które nie mają żadnego oficjalnego statusu.

Warto w tym miejscu odnotować, że język regionalny i język mniejszościowy to terminy, które zostały przyjęte do klasyfikacji rdzennych języków Europy, niebędących jednak językami oficjalnymi danego państwa. W The European Charter for Regional and Minority Languages (1992: 2) zostały one zdefiniowane jako „traditionally used within a given territory of a State by nationals of that State who form a group numerically smaller than the rest of the State's population and different from the official language(s) of that State" ${ }^{\prime 15}$ z jednoczesnym zaznaczeniem, że „it does not include either dialects of the official language(s) of the State or the languages of migrants". W podobnym tonie wypowiada się również J. Cummins (2008: 1) pisząc, w odniesieniu do unique minority languages ${ }^{16}$, że ,[t] tional utility beyond their immediate territorial zone and are seldom even required within that zone because virtually everyone is fluent in the dominant language". Języki regionalne i mniejszościowe zostały ujęte w cztery kategorie:

\footnotetext{
${ }^{14}$ Według J. Cenoz i D. Gorter (2008) 40\% światowej populacji posługuje się jako językiem pierwszym jednym z ośmiu najczęściej używanych języków świata, tj.: mandaryńskim, hindi, hiszpańskim, angielskim, bengalskim/ bengali, portugalskim, arabskim i rosyjskim.

${ }^{15}$ Powyższa definicja, jak stwierdzają J. Cenoz i D. Gorter (2008: 5), wywodzi się od tej podanej w Special Rapporteur Capotorti z 1979 roku, która definiuje mniejszość jako: ,a group numerically inferior to the rest of the population of a State, in a non-dominant position, whose members - being nationals of the State - possess ethnic, religious, or characteristics differing from those of the rest of the population and show, if only implicitly, a sense of solidarity, directed towards preserving their culture, traditions, religion or language."

${ }^{16}$ Taką nazwą posługują się redaktorzy tomu 21 AILA Review: J. Cenoz/ D. Gorter (2008).
} 
- języki autochtoniczne (będące językami rdzennymi, lecz nie państwowymi):

[a]utochthones languages are languages that originated in a specified place and were not brought to that place from elsewhere. Autochthones languages are spoken usually within a part or parts of a member state, but are not the majority language of that state or even the region, for example, Welsh in Wales (M.P. Jones 2013: 21).

- języki autochtoniczne i ponadgraniczne (będące językami rdzennymi i występujące w co najmniej dwóch państwach, niebędące jednak językami państwowymi):

[a]utochthones languages which are also cross border are languages which are not the main state language, for example, Basque in Spain but are also spoken across the border in another member state, where they are not the main state language there either, e.g. Basque in France, and North Sami in Sweden and Finland (M.P. Jones 2013: 22).

- języki ponadgraniczne (funkcjonujące jako język państwowy jednego państwa oraz język mniejszościowy innego):

[c]ross border languages are languages spoken by a minority language group in one member state, but the language exists also in another state. The crossborder language is often the majority language in the neighbouring state (M.P. Jones 2013: 22).

- języki pozaterytorialne (takie jak romani):

[t]he fourth category is the non-territorial languages such as Roma and Yiddish. Romani is incontestably the most widespread non-territorial language in the world. It is sometimes treated as seven languages; Carpathian Romani, Kalo Finnish Romani, Baltic Romani, Balkan Romani, Sinte Romani, Welsh Romani and Vlach ('Vlax') Romani, but the Romani dialects preserve a remarkable degree of unity, which has led to the current treatment of Romani as a single language. Both Roma and Yiddish are included as endangered languages in the Atlas, and these languages receive little support from European or member state sources (M.P. Jones 2013: 21).

Atlas of the World's Languages in Danger ${ }^{17}$, opracowany przez UNESCO (Ch. Moseley 2010), zawiera informacje o 128 językach w Unii Europejskiej, które zostały uznane za zagrożone wymarciem, a dany ,[j]ęzyk jest zagrożony wymarciem, gdy osoby mówiące tym językiem przestają się nim posługiwać, gdy stosują go w stale malejącej liczbie obszarów komunikacji i gdy przestaje on być przekazywany z pokolenia na pokolenie. Oznacza to, że nie ma nowych użytkowników tego języka, ani dorosłych, ani dzieci"'(UNESCO 2003 (w: M.P. Jones 2013: 4). Ramy klasyfikacji żywotności języków przewidują 7 poziomów żywotności (z czego pięć odnosi się do języków zagrożonych): 1) bezpieczny (safe), 2) stabilny, lecz zagrożony (stable yet threatened), 3) podatny na zagrożenia (vulnerable), 4) zdecydowanie zagrożony (definitely endangered), 5) poważnie zagrożony (severely endangered), 6) krytycznie zagrożony (critically endangered), 7) wymarły (extinct) (Ch. Moseley 2010). Spośród przywołanych 128 języków, określa się mianem:

${ }^{17}$ Opublikowana w latach dziewięćdziesiątych przez UNESCO Czerwona księga zagrożonych języków (oryg. The Red Book of Endangered Languages 1993) została zastąpiona przywołanym powyżej Atlasem zagrożonych języków świata; wszystkie języki uznawane za odrębny język, a nie dialekt, mają własny kod ISO. 
- podatnych na zagrożenia - 22, takich jak na przykład: język baskijski (Basque), język walijski (Welsh);

- zdecydowanie zagrożonych - 40, takich jak na przykład: język karelski (Karelian), język friulski (Friulian), języki łużyckie - dolnołużycki i górnołużycki (Sorbian);

- poważnie zagrożonych - 41, takich jak na przykład: język kaszubski (Kashubian), język szkocki (Scots), języki lapońskie (Sami), język bretoński (Breton);

- krytycznie zagrożonych - 10, takich jak na przykład: język liwski/ liwoński (Livonian $^{18}$, język kornijski (Cornish);

- wymarłych ${ }^{19}-11$, takich jak na przykład: język mozarabski (Mozarabic), język kemi (Kemi Sami), język auregnais (Alderney French) (M.P. Jones 2013 za: Ch. Moseley 2010).

W kontekście polskim, biorąc pod rozwagę niżej wymienione kategorie, warto odnotować następujące dane:

- języki ujęte w Europejskiej karcie języków regionalnych lub mniejszościowych: język ormiański/armeński (Armenian), język białoruski (Belorussian), język czeski (Czech), język niemiecki (German), język hebrajski (Hebrew), język karaimski (Karaim), język kaszubski (Kashub), język łemkowski (Lemko), język litewski (Lithuanian), język romski/ romani (Romani), język rosyjski (Russian), język słowacki (Slovak), język tatarski (Tatar), język ukraiński (Ukrainian), język jidysz (Yiddish);

- języki nie ujęte w Europejskiej karcie języków regionalnych lub mniejszościowych: język śląski (Silesian);

- języki ujęte w Atlasie zagrożonych języków świata: język białoruski (Belorussian), język kaszubski (Kashubian), język dolnosaksoński (Low Saxon), język poleski (Polesian), język romski/ romani (Romani), język rusiński (Rusyn), język słowiński (Slovinician [sic!] - Slovincian], język wilamowski (Vilamovian), język jidysz (Yiddish) (M.P. Jones 2013).

$\mathrm{Na}$ koniec, bardzo trafne uwagi w świetle rozważań niniejszego tekstu, a zwłaszcza w kwestii wieloznaczności samego wyrazu ,język" (tj. rozbieżności w jego zdefiniowaniu), prezentuje F. Grucza (2017b). Według niego, określenia w rodzaju „naturalny (żywy) język ludzki” (ujednoznacznione poprzez odpowiednią „obudowę przymiotnikową”) są mniej wieloznaczne niż sam tylko wyraz ,język". Nie oznacza to jednak, że przywołane wyrażenie można uznać za jednoznaczne, bowiem może się ono odnosić do języka ludzkiego w ogóle, pojmowanego jako wspólny składnik wszystkich języków (w wymiarze całego ludzkiego gatunku). Poza tym:

[...] w zakres znaczeniowy wyrazu ,język" mogą wchodzić różne - dowolnej wielkości i jakości - zbiory istniejących środków i sposobów porozumiewania się międzyludzkiego

\footnotetext{
${ }^{18}$ Według informacji dostępnych pod hasłem język liwski w: „Wikipedia” język ten został uznany za wymarły, a ostatnia osoba, dla której był językiem ojczystym, p. Grizelda Kristina, zmarła, w wieku 103 lat, 2 czerwca 2013 roku, w Kanadzie (URL https://pl.wikipedia.org/wiki/J\%C4\%99zyk_liwski). [Pobrano 5.7.2017].

${ }^{19}$ Od roku 1950.
} 
- od zbioru, którym posługuje się dowolna pojedyncza osoba, począwszy, aż po taki, który nazwać można by zbiorem wszechobejmującym. To ten właśnie ciąg zbiorów jest brany pod uwagę, gdy wyróżnia się języki różnych grup czy wspólnot etnicznych (np. plemiennych lub narodowych), społecznych, zawodowych itp., albo języki różnych grup zdeterminowanych przestrzennie (geograficznie) i/ lub czasowo (historycznie). Natomiast w niewyraźnym odróżnieniu wynikających stąd różnych znaczeń wyrazu ,język (ludzki)” tkwi - jak sądzę - główny powód sporów o to, czy język określonej grupy ludzi, w szczególności jakiejś wspólnoty, jest dialektem jakiegoś „,obszerniejszego” języka, tzn. języka jakiejś większej wspólnoty (np. narodowej), czy też językiem odrębnym, samodzielnym (por. w tym związku na przykład znany spór o status kaszubszczyzny). Pytanie, czy dialekt, gwara, żargon itp. warianty realizacyjne języków są językami czy nie są, a jeśli są (nie są), to w jakim sensie są nimi (lub nie są), wymaga po prostu w ogóle dokładniejszego rozważenia (S. Grucza i in. 2017b: 46).

Co więcej, zdaniem Autora (ibid.), istnieją jeszcze dwie inne przyczyny wieloznaczności wyrażenia „naturalny (żywy) język ludzki”. Otóż, to, co czasem nazywa się ,językiem”, w innych okolicznościach można nazwać „mową”/ „mówieniem”; można też użyć tego określenia w kierunku do realizowanych ustnie bądź pisemnie wypowiedzi w postaci zdania lub tekstu/ tekstów. Na koniec tychże rozważań, F. Grucza (ibid.) stwierdza, że trzeci rodzaj wieloznaczności wyrażenia „naturalny (żywy) język ludzki" ma swe źródło w fakcie, że jednoznaczny nie jest ani użyty w nim wyraz „ludzki”, ani wyraz „naturalny” bowiem w komunikacji międzyludzkiej, ludzie korzystają z różnych środków i sposobów (nie tylko tych specyficznie ludzkich, ale także takich, które są atrybutem niektórych zwierząt).

\subsection{Język walijski}

Walijski, a pierwotnie Cymraeg, jest językiem należącym do grupy brytańskiej języków celtyckich - jego późniejsza nazwa wywodzi się od anglosaksońskiego słowa Wealas (tj. obcy), którym określani byli Celtowie. Pierwsze ślady języka identyfikowanego z walijskim, a który zyskał miano wczesnowalijskiego, sięgają wieku szóstego - po nim mamy do czynienia z okresem starowalijskim trwającym od wieku dziewiątego do wieku jedenastego. Następne okresy, zdaniem historyków języka (A. Baugh/ T. Cable 2002), to okres średniowalijski trwający od wieku dwunastego do wieku czternastego (język w owej postaci jest zrozumiały zresztą dla współczesnego

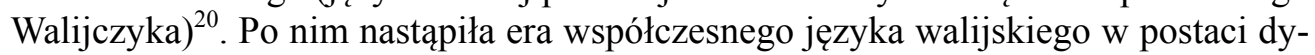
chotomii: wczesny współczesny walijski (trwał on od piętnastego do końca szesnastego stulecia) oraz późny współczesny walijski (zapoczątkowany w roku 1588, tj. roku, w którym Morgan ukończył przekład Biblii).

${ }^{20} \mathrm{~W}$ wyniku kolonizacji Walii przez Anglię na przełomie czternastego i piętnastego wieku, walijski, w następstwie przebiegającej anglicyzacji, stał się językiem mniejszościowym. Co więcej, w 1536 roku angielski parlament na mocy ustawy The Act of Union wcielił Walię w skład Anglii z jednoczesnym zaznaczeniem, że brak znajomości angielskiego jest dla Walijczyków czynnikiem dyskwalifikującym w pełnieniu jakiejkolwiek publicznej funkcji (A. Baugh/ T. Cable 2002). 
Według danych ze Spisu Powszechnego z 2011 roku, językiem walijskim posługuje się nieco ponad 560 tysięcy osób (tj. ok. 18\% wszystkich mieszkańców Walii); z kolei $14 \%$ społeczeństwa potrafi czytać, pisać oraz mówić w tym języku - i/ lub w jednym z czterech jego głównych dialektów: wenedocjańskim, powyskim, domeckim i gwenckim; liczbę osób mówiących w języku walijskim na obszarze Walii wyrażoną w procentach przedstawia rys. 1. Warto zauważyć, że liczba osób posługująca się wyłącznie walijskim spadła z 30\% w 1891 roku do $2 \%$ w roku 1950 (A. Baugh/ T. Cable 2002). Obecnie walijski podlega ochronie prawnej zgodnie z ustawą z 1993 roku (The Welsh Language Act).

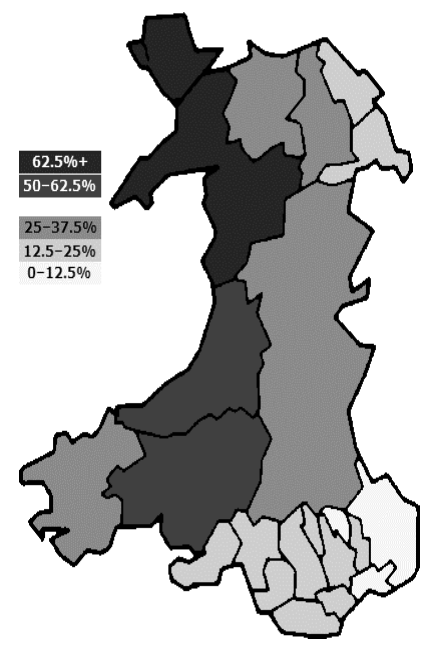

Rysunek 1. Liczba osób mówiących językiem walijskim na obszarze Walii w procentach (Język walijski w: ,Wikipedia” 2017)

W latach sześćdziesiątych, siedemdziesiątych i osiemdziesiątych ubiegłego stulecia nastąpił wzrost w liczbie dzieci wybierających naukę w języku walijskim (których rodzice nie posługiwali się tymże językiem); edukacja ta przebiegała w oparciu o zasady językowej immersji ${ }^{21}$ (C. Baker 2006). Według informacji statystycznych zaprezentowanych przez Welsh Assembly Government w 2007 roku istniało 466 szkół podstawowych, których uczniowie posługiwali się językiem walijskim. Tym samym odsetek uczniów komunikujących się w języku walijskim wzrósł w porównaniu z rokiem 1987 z 24,6\% do 36,5 w 2007 roku. W wymiarze szkoły średniej natomiast ponad 15\% uczniów w klasach 7-11 uczyło się walijskiego jako języka pierwszego (a blisko $84 \%$ - jako języka drugiego ${ }^{22}$.

${ }^{21}$ Choć oczywiście nie tylko, bowiem w Walii istnieją różne typy szkół: walijskojęzyczne, dwujęzyczne oraz uczenie się walijskiego jako obcego.

${ }^{22}$ Równie ciekawe wnioski prezentują wyniki innych badań - dla porównania zob. np.: J. Cenoz (2008), F. Xavier Vila i Moreno (2008), J. Harris (2008), D. Gorter/ C. van der Meer (2008), R. Johnstone (2009), R. Rubdy/ T.R.F. (2009), 


\section{Konkluzja}

Pionierskie badania nad rozwojem dwujęzyczności rozpoczął w pierwszej połowie ubiegłego wieku J. Ronjat. ${ }^{23}$ Późniejsze badania, z których wiele było studiami przypadku poszczególnych państw lub społeczeństw podkreślających uznanie historii, polityki czy demografii, powojenne ruchy migracyjne, postkolonialną politykę językową, propagowanie humanistycznych i egalitarnych ideologii (A. Lam 2006), potwierdzały kolejno, że dwujęzyczne dzieci nie różnią się w niczym od swoich jednojęzycznych rówieśników poza tym, że znają one dwa języki, a nie jeden (W. Klein 1986). Nie będzie zbyt odkrywczą konstatacją, że, ,(...) bilinguals (and multilinguals) have a unique form of language competence that is not necessarily comparable to that of monolinguals because learning a second or additional language has an influence on the whole cognitive system. Second language users possess unique forms of competence, or competencies, in their own right and should not be seen as the sum of two monolinguals" (J. Cenoz 2008: 27 za: V. Cook 1995, 2002). Korzyści płynące ze znajomości dwóch lub więcej języków są niepodważalne - zarówno w wymiarze jednostki, organizacji, jak i całych społeczeństw. Wśród nich jest także ten w postaci gratyfikacji finansowej: przeprowadzone badania (A. Henley/ R. Jones 2000, 2013), na przykładzie Walii, dowodzą, że osoby dwujęzyczne (tu: ze znajomością języka walijskiego) zarabiały średnio od 8 do 10 procent więcej.

Błędem jest jednak, jak podkreśla C. Baker (2006), brak rozróżnienia pomiędzy edukacją dwujęzyczną pojmowaną jako fenomen dwudziestego wieku poparty: a) narodzinami różnego typu programów edukacyjnych w Stanach Zjednoczonych w latach sześćdziesiątych i siedemdziesiątych, b) powstaniem w przedszkolu w St Lambert (Montreal) w roku 1965 pierwszej eksperymentalnej klasy, c) utworzeniem Wolnego Państwa Irlandii w 1922 roku, d) powołaniem do życia w 1939 roku pierwszej szkoły podstawowej (Ysgol Gymraeg) w Walii (w Aberystwyth), w której środkiem komunikacji był język walijski, a dwujęzycznością w ogóle. Ta ostatnia istniała bowiem w takiej czy innej postaci od pięciu tysięcy lat (C. Baker 2006 za: W.F. Mackey $1978)^{24}$, dlatego ważnym jest, aby nie odrywać współczesnej edukacji dwujęzycznej od jej historycznych korzeni rozpatrywanych w kontekście dawnej imigracji czy ruchów politycznych. Poza tym, „(...) teaching the [unique minority, M. Ł.] language as a subject generally produces disappointing results in comparison to immersion or bilingual programs. If the teaching of the language is not developing expertise, then students do not experience identity enhancement" (J. Cummins 2008: 2).

\footnotetext{
${ }^{23} \mathrm{Na}$ uwagę zasługują również osiągnięcia w tym obszarze dokonane przez W. Leopolda czy prace W. Penfielda i W. Lamberta zebrane i opublikowane przez E. Peal i W. E. Lamberta (1962).

${ }^{24}$ Zob. także E. G. Lewis $(1977,1981)$.
} 


\section{Bibliografia}

Acculturation. Anthropology (2006), (w:) „Encyclopaedia Britannica”. (URL http://www.britannica.com/topic/acculturation.). [Pobrano 18.02.2016].

Atger, A.F. (2009), Education and political participation of migrants and ethnic minorities in the EU, (w:) „Centre for European Policy Studies”. (URL http://www.ceps.eu). [Pobrano 03.02.2017].

Baker, C. (2006), Foundations of bilingual education and bilingualism (4 ${ }^{\text {th }}$ ed.). Clevedon.

Baugh, A./ T. Cable (2002), A history of the English language ( $5^{\text {th }}$ ed.). London.

Berry, J.W. (1997), Immigration, acculturation, and adaptation, (w:) „Applied Psychology" 46 (1), 5-34.

Bialystok, E. (2001), Bilingualism in development. Language, literacy, and cognition. Cambridge.

Budyta-Budzyńska, M. (2010) Socjologia narodu i konfliktów etnicznych. Warszawa.

Cenoz, J. (2008), Achievements and challenges in bilingual and multilingual education in the Basque Country, (w:) „Multilingualism and minority languages. AILA Review" 21, 13-30.

Cenoz, J./ D. Gorter (2008), Applied Linguistics and the use of minority languages in education, (w:) „Multilingualism and minority languages. AILA Review” 21, 512.

Cook, V. (1995), Multi-competence and the learning of many languages, (w:) „Language, Culture and Curriculum" 8, 93-98.

Cook, V. (2002), Background to the L2 user, (w:) V. Cook (red.), Portraits of the L2 user. Clevedon, 1-28.

Council Resolution of 21 November 2008 on a European strategy for multilingualism (2017), (w:) „Eur-Lex”. (URL http://eur-lex.europa.eu/legal-content/EN/TXT/PDF/?uri=CELEX:32008G1216(01)\&from=EN). [Pobrano 09.06.2017].

Crystal, D. (2000), Language death. Cambridge.

Cummins, J. (2008), Foreword, (w:) "Multilingualism and minority languages. AILA Review" 21, 1-3.

Davies, J. (1993), The Welsh Language. Cardiff.

Ethnic group (2016), (w:) „Encyclopaedia Britannica”. (URL http:/www.britannica.com/topic/ethnic-group). [Pobrano 05.03.2016].

Gordon, R.G. (red.) (2005), Ethnologue: languages of the world, $15^{\text {th }}$ ed, (w:) ,Ethnologue". (URL http://www.ethnologue.com/13/). [Pobrano 01.07.2017].

Gorter, D./ C. van der Meer (2008), Developments in bilingual Frisian-Dutch education in Friesland, (w:) „Multilingualism and minority languages. AILA Review”, 87-103.

Grimes, B.F. (red.) (1996). Ethnologue. Languages of the World, (w:) „Ethnologue”. (URL http://www.ethnologue.com/13/). [Pobrano 01.07.2017].

Grucza, F. (1981). Glottodydaktyczne implikacje bilingwizmu, (w:) F. Grucza (red.), Bilingwizm a glottodydaktyka. Warszawa, 9-35. 
Grucza, F. (2017a), Franciszek Grucza. Dzieła zebrane, t. 9: Lingwistyka stosowana. Historia-Zadania-Osiagnięcia. S. Grucza/ M. Olpińska-Szkiełko/ M. Płużyczka/ I. Banasiak/ M. Łączek/ A. Bonek/ A. Kaleta/ A. Sztuk (red.), Warszawa. (URL: http://www.iksi.uw.edu.pl/documents/11738337/14640936/FG_Tom_9.pdf). [Pobrano 04.07.2017].

Grucza, F. (2017b), Franciszek Grucza. Dzieła zebrane. Tom 3. O języku, językach $i$ lingwistyce. S. Grucza/ M. Olpińska-Szkiełko/ M. Płużyczka/ I. Banasiak/ M. Łączek/ A. Bonek/ A. Kaleta/ A. Sztuk (red.), Warszawa (URL http://www.iksi.uw.edu.pl/documents/11738337/14640936/FG_Tom_3.pdf). [Pobrano 04.07.2017].

Grucza, S. (2013), Od lingwistyki tekstu do lingwistyki tekstu specjalistycznego. Warszawa.

Harris, J. (2008), The declining role of primary schools in the revitalisation of Irish, (w:) „Multilingualism and minority languages. AILA Review” 21, 49-68.

Język walijski (2017), (w:) „Wikipedia”. (URL https://pl.wikipedia.org/wiki/J\%C4\%99zyk_walijski). [Pobrano 07.07.2017].

Języki urzędowe UE (2017), (w:) „European Commission. Kształcenie i szkolenie”. (URL http://ec.europa.eu/education/policy/linguistic-diversity/official-languageseu_pl). [Pobrano 07.07.2017].

Johnstone, R. (2009), Review of research on language teaching, learning and policy published in 2007, (w:) „Language Teaching. Surveys and studies” 42 (3), 287-315.

Jones, M.P. (2013), Endangered languages and linguistic diversity in the European Union. (URL http://www.europarl.europa.eu/RegData/etudes/note/join/2013/495851/IPOL-CULT_NT(2013)495851_EN.pdf). [Pobrano 05.07.2017].

Kurcz, I. (2007), Psychologiczne aspekty dwujęzyczności. Gdańsk.

Kurmanowa, B. (2009), Wspótczesna językowa i etnojęzykowa sytuacja w Kazachstanie i jej wpływ na ksztaltowanie dwujęzyczności w nauczaniu (na przykładzie ośrodków naukowych Aktiubiń- skiego Okręgu Republiki Kazachstanu), (w:) „Lingwistyka Stosowana/ Applied Linguistics/ Angewandte Linguistik" 1, 141-149;

Łączek, M. (2006), Angielskie zadziwienia, (w:) „Głos Nauczycielski” 49, 13.

Łączek, M. (2015a), Szkolnictwo polonijne w kontekśsie egzolingwalnym (na przykładzie Zjednoczonego Królestwa Wielkiej Brytanii i Irlandii Pólnocnej). Od 'polskiej szkoty parafialnej' po 'Polish abroad Saturday school'. Odczyt na Konferencji „Nauczanie języków obcych - nowe czasy, stare problemy”. Lublin: 1314.11.2015 r.

Łączek, M. (2015b), Ksztatcenie andragogiczne a walka z bezrobociem (na przyktadzie polskiej mniejszości etnicznej zamieszkującej londyńska gminę Ealing, (w:) „Proceedings of the International Scientific Conference on MMK 2015. International Masaryk Conference for Ph.D. Students and Young Researchers, Volume VI", 1251-1262.

Łączek, M. (2016a), Glottodydaktyka dwujęzyczna: przeglad polskiej i angielskiej terminologii, (w:) „Lingwistyka Stosowana” 19: 4/2016, 77-89. 
Łączek, M. (2016b), Akulturacja polskich (e/i)migrantów: „,zjednoczeni w różnorodności”? Odczyt na II Międzynarodowej Konferencji Online „Nowy wymiar filologii - języki, literatura, językoznawstwo, kultura”. Płock: 18-24.04.2016.

Łączek, M. (2017a), Glottodydaktyka dwujęzyczna: przeglad stanu badań, (w:) „Studia Niemcoznawcze. Czasopismo naukowe Zakładu Komparatystyki Kulturowej i Literackiej Instytutu Germanistyki Uniwersytetu Warszawskiego", Tom LX, 857870.

Łączek, M. (2017b), Funkcja facylitacyjna angielskiej polityki oświatowej w zakresie kształcenia mniejszości etnicznych (przypadek inspektoratu oświaty w Milton Keynes). Odczyt na „26. Konferencji PTLS. Konferencja Polskiego Towarzystwa Lingwistyki Stosowanej”. Zielona Góra: 07-08.04.2017.

Łączek, M. (2018), Brytyjscy Polacy - polscy Brytyjczycy: osiagnięcia młodego pokolenia na egzaminie GCSE z języka polskiego, (w:) „Neofilolog. Czasopismo Polskiego Towarzystwa Neofilologicznego" 49/2, 257-272.

Lam, A. (2006). Bilingualism, (w:) R. Carter/ D. Nunan (red.), The Cambridge guide to teaching English to speakers of other languages. Cambridge, 93-99.

Laskowski, R. (2009), Język w zagrożeniu. Przyswajanie języka polskiego $w$ warunkach polsko-szwedzkiego bilingwizmu. Kraków.

Lewis, W. (2008), Current challenges in bilingual education in Wales, (w:) „Multilingualism and minority languages. AILA Review" 21, 69-86.

Lipińska, E. (2013), Polskość w Australii. O dwujęzyczności, edukacji i problemach adaptacyjnych Polonii na antypodach. Kraków.

Lipińska. E./ A. Seretny (2012), Między językiem ojczystym a obcym. Nauczanie $i$ uczenie sie języka odziedziczonego na przykładzie chicagowskiej diaspory polonijnej. Kraków.

Moseley, Ch. (red.) (2010). Atlas of the World's Languages in Danger, 3. wyd. (2017). (URL http://www.unesco.org/new/en/culture/themes/endangered-languages/atlas-of-languages-in-danger/). [Pobrano 13.07.2017].

Olpińska-Szkiełko, M. (2013), Wychowanie dwujęzyczne w przedszkolu. Warszawa.

Peal, E./ W.E. Lambert (1962), The relation of bilingualism to intelligence, (w:) „Psychological Monographs: General and Applied" 76 (27), 1-23.

Rubdy, R./ T.R.F. Tupas, Research in applied linguistics and language teaching and learning in Singa-pore (2000-2007), (w:) „Language Teaching. Surveys and studies" $42(3,317-340$.

Ryan E.B./ H. Giles (red.) (1982), Attitudes towards language variation: social and applied contexts. London.

Xavier Vila i Moreno, F. (2008), Language-in-education policies in the Catalan language area, (w:) „Multilingualism and minority languages. AILA Review” 21, $31-48$. 